\title{
ON THE REVOLUTION OF THE FOUR HUNDRED AT ATHENS.
}

THE copious discussion which has been raised in recent years on the subject of the Four Hundred at Athens has brought out at any rate one certain conclusion. Of our two main authorities for the revolution of 411 B.c. neither Thucydides nor Aristotle can be pronounced entirely right or wrong, and it is no longer admissible to settle the differences between them by canonising the one and ruling the other out of order. Both our authorities can be convicted of some palpable mistakes, but again both can be proved right by collateral evidence on many points of detail. In reconstructing the history of the movement our choice between these two sources must therefore not be made on the ground of any $\alpha$ priori preference accorded to the one or the other. The only safe procedure is to adjudicate each question outstanding between them on the special merits of the case. It is not to be expected that even by this method finality can be attained. But a review of recent controversy will show that only by a pragmatic method of treatment is there much chance of collecting a nucleus of agreed truth. ${ }^{1}$

The object of the present article is to consider in turn the chief points of variance between Thucydides and Aristotle, and to determine whose authority is the better in each particular case.

\section{A.-The $\xi \nu \gamma \gamma p a \phi \in \hat{\imath}$ s. Number and Date of Appointment.}

The first ámopía in the story of the revolution relates to the number of the $\xi v \gamma \gamma \rho a \phi \epsilon i s$ who were commissioned in the early stages of the movement to draft a revision of the democratic constitution, and to the connexion between this Revising Committee and the board of $\pi \rho{ }^{\beta} \beta o v \lambda o \iota$, or

1 The following are the chief contributions to the discussion in the past few years:-(1) Ed. Meyer, Forschungen, ii. pp. 411-436 ; (2) Köhler, Ber. Berl. Akad. 1900, pp. 803-817; (3) Costanzi, Riv. di Filologia, 1901, pp. 84108 ; (4) Busolt, Griech. Geschichte, iv. pp. 1456-1513 ; (5) May, Die Oligarehie der 400 in Athen im Jahre 411 (Halle, 1S07); (6) Judeich, Rhein. Museum, 1907, pp. 295-308; (7) Kuberka, Klio, 1907, pp. 341-356; 1908, pp. 206-212 ; (8) Kriegel, Der Staatsstreieh der $V$ ierhundert in Athen 411 v. Chr. (Bonn, 1909); (9) Siegmund, Thukydides und Aristoteles über H.S.-VOL. XXXIII. die Oligarchie des Jahres 411 in Athen (Böhmisch-Leipa, 1909) ; (10) U. Kahrstedt, Forschungen (Berlin, 1910), pp. 237-266 ; (11) Sadl, Die oligarchische Revolution vom Jahre 411 (Pola, 1910) ; (12) Ledl, Weiner Studien, 1910, pp. 38-54; (13) A. v. Mess, Rhein Mruseum, 1911, pp. 366-79.

The present author is chiefly indebted to the treatises of Ed. Meyer and Kahrstedt. He has been unable to see the article by Volquardsen in Verhandlungen der 48 Philologenversammlung in Hamburg, 1905. 
Commissioners of Ways and Means, who had been appointed soon after the catastrophe of the Sicilian Expedition to devise economies in administration. Thucydides ${ }^{2}$ mentions but ten $\xi v \gamma \gamma \rho a \phi \epsilon \hat{\imath} s$, whom he does not bring into relation with the $\pi \rho$ ó $\beta o u \lambda o c$; Aristotle ${ }^{3}$ records a total of thirty $\xi \nu \gamma \gamma \rho a \phi \in \hat{\imath} s$, and asserts that these included the $\pi \rho$ ó $\beta o v \lambda o$, together with twenty additional members elected ad hoc.

This problem hardly needs further discussion. There is sufficient independent evidence to show that Aristotle is right in both counts, and that Thucydides has made a mistake with regard to the the number of the $\xi v \gamma \gamma p a \phi \epsilon i s .{ }^{4}$

A second and more important question concerns the date at which the $\xi v \gamma \gamma p a \phi \in \hat{s}$ sere instituted. Thucydides makes their appointment follow upon the return of Peisander from his tour round the Aegean Sea (May 411) ${ }^{5}$; Aristotle ${ }^{6}$ connects them with Peisander's previous visit, when he laid before the Ecclesia the pretended offer of help from the king of Persia (end of 412).

In this case Aristotle again deserves preference. The current in favour of constitutional reform, of which the Revising Committee was the outcome, had been flowing in Athens long before the second advent of Peisander: indeed Thucydides himself points to its existence as far back as 413 B.c. ${ }^{7}$ It is most unlikely that the sentiment in favour of reform should have remained ineffective for the greater part of two years, the more so as the Athenians had meanwhile opened negotiations with Persia on the very understanding that they should make their government more oligarchic, and therefore were bound at least to make a show of constitutional reform. $^{8}$

2 viii. $67, \S 1$.

3 Ath. Pol. 29. § 2.

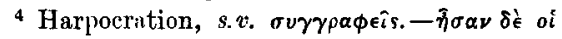

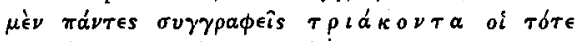

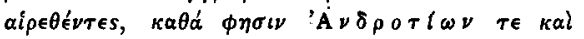
$\Phi$ ¿ $\lambda$ ó $\chi$ opos.

The inclusion of the $\pi \rho$ ó Boviot in the board of $\xi v \gamma \gamma \rho \alpha \phi \epsilon i s$ is attested by the fact that they were commonly held responsible for the subsequent revolution (Lysias, xii. 65; Arist. Rhet. iii. 18. 2). This belief could never have sprung up if the $\pi \rho$ óboviol had always been restricted to their original administrative functions.

Costanzi (loc. cit. pp. 89-91) has endeavoured to rescue Thucydides' authority by explaining away the excedent $20 \xi v \gamma \gamma \rho \alpha \phi \epsilon i s$ as mere ciphers, and by declaring the identity between

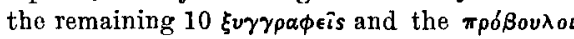
to be accidental. But nobody is likely to believe in a tenfold coincidence such as be

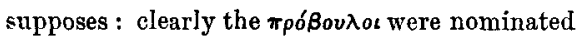
as such to the Revising Committee, whose referenee included inter alia economic reforms such as the $\pi \rho \delta$ Bou to initiate. As to the supplementary members, it is quite arbitrary to assume that they were men of straw, and even if this were the case it would not alter the fact that officially they were

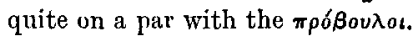

5 viii. $67, \S 1$. The chronology is Busolt's.

$629, \S 1$.

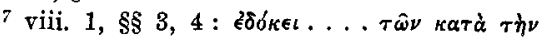

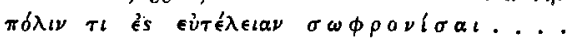

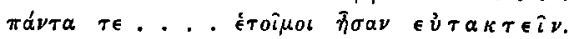

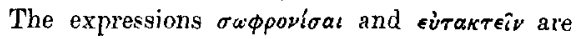
significant: they were current euphemisms for an oligarchic type of government.

The mere fact of $\pi \rho b \beta o v \lambda a s$ having been appointed to mend the finances in itself suffices to prove that the Athenians were contemplating some changes in their constitution. Financial reform could not be carried to any length without the restriction of $\mu \iota \sigma \theta \delta s$, and $\mu \iota \sigma \theta \delta s$ was the

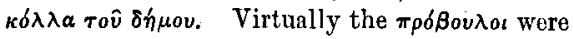
a Revising Committee from the first.

8 Thuc. viii. 53-4. 
Some further considerations will also be found to tell against the account of Thucydides. It may be taken for granted that Peisander lost no time after his second arrival at Athens in carrying out the coup d'état by which the Four Hundred actually rose to power. ${ }^{2}$ He had brought with him a posse of hired bandits who remained on his hands as a sheer deadweight until the revolution should have been effected. Apart from the suspicion which might attach to the protracted sojourn of such unusual visitors in Athens, the mere expense of their upkeep must have induced Peisander to incur no delay in delivering his blow. On the other hand the work of the $\xi v \gamma \gamma p a \phi \in i$ is obviously required an ample amount of leisure. Let alone any effective scheme of reform, not even a plausible programme could have been compiled by them in the brief interval which was all that Peisander could concede to them after his second arrival. But unless the $\xi u \gamma \gamma \rho a \phi \in i$ s were to give at any rate the appearance of having some serious proposals to submit to the Ecclesia, and to that extent were to invest the revolution with a show of legality, one fails to see why Peisander ever troubled to have them appointed. It was as much in the interest of the revolutionists as of all moderate reformers that the $\xi$ vrypapeis should be instituted at an early date: an eleventh-hour appointment could have served nobody.

The evidence therefore is distinctly in favour of Aristotle's as against 'Thucydides' date for the creation of the board of $\xi v \gamma \gamma \rho a \phi \epsilon i s$.

\section{B.-The Report of the $\xi v \gamma \gamma \rho a \phi \in \hat{\imath}$ s.}

There follows a трлкupia of perplexities. The central stages of the revolution are narrated so diversely by our two authorities that it seems impossible to dovetail their texts at all satisfactorily. As a matter of fact all critics who have attempted this jigsaw puzzle have been compelled either to discard some of the bits or to trim them with surreptitious scissors. The only certain conclusion is that the divergent accounts of Thucydides and Aristotle are quite irreconcilable.

Our first problem is to discover what were the contents of the report which the $\xi v \gamma \gamma p a \phi \epsilon i s$ in due course of time laid before the Ecclesia. Thucydides maintains stoutly that they made one recommendation, and no more, viz. the suspension of all checks upon freedom of legislation. ${ }^{10}$ Aristotle on the other hand makes them responsible for the entire order of the day, which included three resolutions of substantial reform : (a) restriction of payment for public service ; $(b)$ limitation of franchise to a select class of citizens with a special property qualification: their number to be 5000 or

9 Thucydides hints as much when he says in

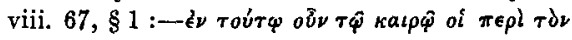

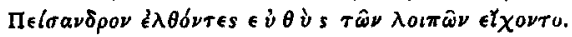

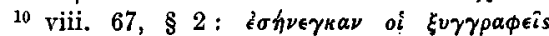

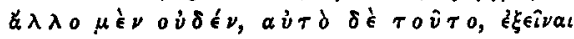

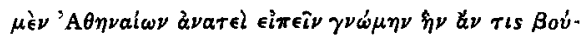

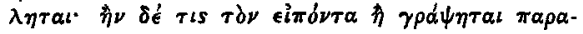

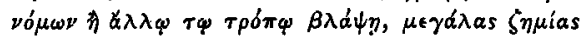
ย่ $\pi \epsilon \in \epsilon \sigma \alpha \nu$. 


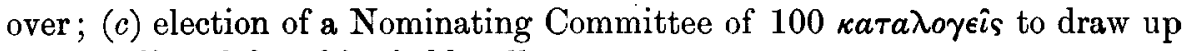
the new list of franchise holders. ${ }^{11}$

In view of the emphasis with which Thucydides asserts that the $\xi \nu \gamma \gamma \rho a \phi \in i s$ merely introduced a preliminary formality, it has been conjectured that he was consciously correcting the tradition reproduced by Aristotle, and that consequently this tradition was erroneous. ${ }^{12}$

But Thucydides' wording of the passage in question is no certain index of his motive in writing it: after all, it may betoken no more than his very natural surprise at the easy-going way in which, according to his account, the $\xi v \gamma \gamma \rho a \phi \epsilon i s$ scamped their work. Still less can it be conceded that Thucydides' polemic, if such it was, must needs be based on superior information. Indeed his version of events is a priori most improbable, for the reticence of the $\xi u \gamma \gamma \rho a \phi \epsilon i$ s defies explanation on any hypothesis. If we suppose, as is most natural, that this body had a free hand in carrying out its duties, it is inconceivable that it should have had nothing further to recommend beside the abolition of the $\gamma \rho a \phi \eta^{\circ} \pi a \rho a \nu{ }^{\prime} \mu \omega \nu$. If we adopt the only alternative view, that the $\xi u \gamma \gamma \rho a \phi \in i$ s had been captured by the revolutionists and on report day acted as a mere instrument of theirs, precisely the same difficulty recurs. The only possible reason which

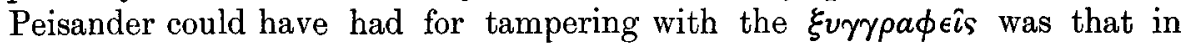
virtue of their popular origin and representative character they might invest his party's usurpation with a greater semblance of constitutional correctness. Consequently it lay in his interest to keep them in the foreground as long as possible, and the very worst thing he could do for himself was to eclipse them before they had fairly come within the public gaze. ${ }^{13}$ Prima facie, therefore, Thucydides' account is less convincing than Aristotle's.

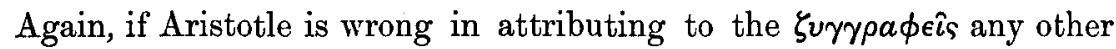

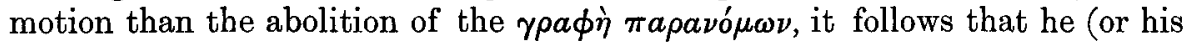
primary authority) did not understand the A B C of diplomatic. The

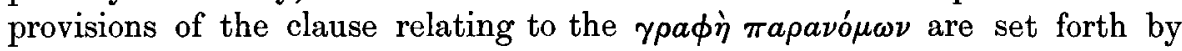

\section{$1129, \$ \S 4,5$.}

An attempt has been made by Meyer (p. 419) to reconcile the two stories by supposing that the substantial resolutions, though technically brought forward by someone else, were in point

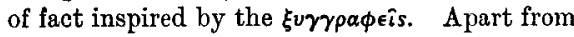
other objections to this view (see below), the emphasis with which Thucydides denies to the $\xi v \gamma \gamma p \alpha \phi \in i s$ any large share in the proceedings of the day shows that they were in his opinion in no wise responsible for the subsequent resolutions.-See esp. Kahrstedt, pp. 243, $250 \mathrm{n}$.

12 Kahrstedt, p. 243. The same author con-

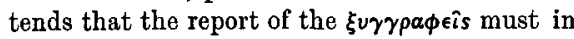
the first instance have been referred to the democratic Council, and that this body would never have sanctioned the reforms which
Aristotle includes in the report, because these were tantamount to its own abolition (pp. 240-1, 245). But $(a)$ in spite of Kahrstedt's arguments it cannot be regarded as certain that the Council had any say in the matter; (b) the reforms enumerated by Aristotle in no way threatened the Council: the new Ecclesia of property holders would have needed a Council to preconsider its business and to direct the magis. trates just as much as the unrestricted Ecclesia ever had done.

13 This consideration tells with no less force against Meyer's theory (see above), that the

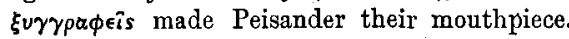
Had there been any collusion, precisely the contrary relation between them might have been expected. 
Aristotle with such fulness and accuracy of terms, that we must credit him (or his authority) with having made first-hand use of an official document. Now such a document would certainly not have ascribed to the $\xi v \gamma \gamma \rho a \phi \in \hat{\imath}$ any motion for which they were not technically responsible. Any riders appended to their proposals, and still more of course any separate motions, would stand in the name of the individual who brought them forward. If Aristotle (or his source) overshot, the mark in copying out the report of the $\xi u \gamma \gamma p a \phi \epsilon i s$, he could only have done so by confusing the headings $\Gamma \nu \omega \mu \eta$

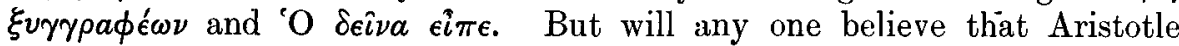
(or his informant) was stupid or careless to such a degree? ${ }^{14}$ Surely he must have known where the $\gamma \nu \omega ́ \mu \eta \xi \nu \gamma \gamma \rho a \phi \epsilon^{\omega} \omega \nu$ began and ended; and if Aristotle's account ascribes to the $\xi u \gamma \gamma \rho a \phi \epsilon i$ s a long list of constructive reforms, we can only infer that these were duly recorded under their name in the official document.

Lastly, there is sufficient collateral evidence to prove conclusively that the restriction of franchise to the Five Thousand and the appointment of $\kappa a \tau a-$ $\lambda o \gamma \epsilon \hat{i}$ s to nominate this body was somehow or other enacted by the Ecclesia. ${ }^{15}$ Failing an alternative explanation of Thucydides ${ }^{16}$ or anyone else, we are bound to assume that these measures were promulgated by the $\xi v \gamma \gamma p a \phi \in i s$ in the manner described by Aristotle.

The conclusion therefore is that the scope of the $\xi v \gamma \gamma \rho a \phi \in i s^{\prime}$ report is defined more accurately in Aristotle than in Thucydides.

\section{C.-The New Constitution and the Method of its Enactment.}

The next point of difference between our sources is the most crucial one

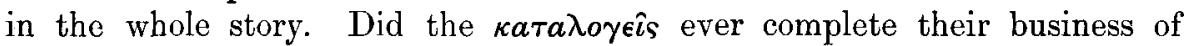
nominating the Five Thousand, and did the members thus appointed ever meet and transact business? Thucydides consistently maintains that they

\footnotetext{
14 Kahrstedt himself confesses in another passage (p. 243) that some limits must be imagined to Aristotle's (or his informant's) power of misinterpreting documents. In arguing against a suggestion by Kuberka (Klio, 1907, pp. 348 sqq.) that the report of the $\xi u \gamma \gamma \rho \alpha \phi \epsilon i s$ as given by Aristotle was not carried in full, but that its constructive portion was overridden hy amendments proposed by Peisander, he justly points out that in this case the official document would have contained not only the

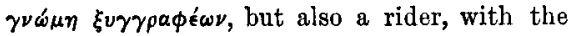

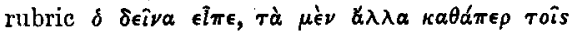
$\xi \cup \gamma \gamma p a \phi \epsilon \hat{v} \sigma \iota \nu$ etc., and that this rider could not well have been overlooked by any one who had made first-hand use of the archives.

15 See the speech Pro Polystrato ([Lysias] Or. $\mathrm{xx}$.). In $\S 13 \mathrm{we}$ read ' $\dot{\boldsymbol{y}} \mu \hat{\omega} \nu$ (i.e. the Athenian Ecclesia) $\psi \eta \phi \iota \sigma \alpha \mu \epsilon \operatorname{\nu \omega \nu } \pi \epsilon \nu \tau \alpha \kappa \iota \sigma \chi \downarrow \iota \lambda$ ioเs $\pi \alpha \rho \alpha \hat{\delta} \sigma \hat{v} \nu a \iota t a \grave{a} \pi \rho \alpha \dot{\gamma} \mu \alpha \tau a$.' This proves beyond
}

doubt that the Five Thousand were a theoretically existent body during the later course of the revolution.

From $\$ 13$ it may be inferred with certainty

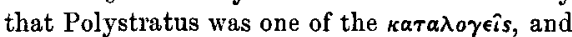

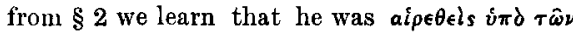
$\phi \nu \lambda \epsilon \tau \hat{\omega} \nu$. This last point tallies exactly with Aristotle's description $(29, \S 5):-\dot{\varepsilon} \lambda \epsilon \sigma \theta \alpha$ ، $\delta^{\prime}$

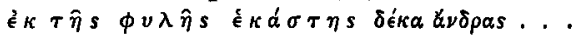

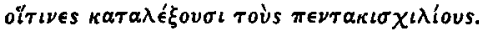

16 Thncydides merely states that the programme put forward by the revolutionists in the early stages of the movement included a restriction of the frauchise to 'not more than 5000' (viii. 65, § 3). But he nowhere indicates when and by whom this scheme was embodied in a bill and put before the Ecclesia.

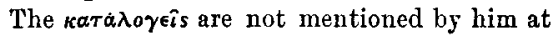
all. 
were never convened or even constituted. ${ }^{17}$ Aristotle in one passage follows Thucydides almost verbatim, ${ }^{18}$ but elsewhere he not only declares that the register of the Five Thousand was completed, but represents this body as taking an effective share in consummating the revolution. ${ }^{19}$

On this point there can fortunately be no doubt as to the verdict. Since the researches of Ed. Meyer ${ }^{20}$ it has been commonly agreed that Thucydides is our better informant.

The elimination of the Five Thousand as an effective factor in the revolution carries with it the disappearance of the two constitutions which Aristotle represents as the formal basis of the usurpers' power. ${ }^{21}$ Although Aristotle does not say in so many words that it was the Five Thousand who enacted these constitutions, ${ }^{22}$ he declares plainly enough that the committee

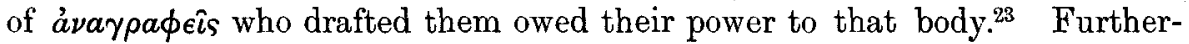
more in the second or 'provisional' constitution there is an explicit reference to the Five Thousand as an assembly in actual being, ${ }^{24}$ and the first or 'definitive' constitution clearly presumes their existence throughout. ${ }^{25}$ Aristotle's 'Instruments of Government' thus stand or fall with the Five Thousand: if the Five Thousand are dispensed with, the constitutions which pre-suppose them must be rejected likewise.

17 viii. $89, \S 2 ; 92, \S 11 ; 93, \S 2$.

18 Ath. Pol. 32, \& 3 .

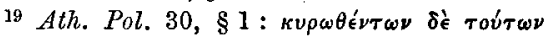
(the report of the $\xi v \gamma \gamma \rho \alpha \phi \epsilon i s) \in \zeta \lambda o \nu \tau o \sigma \phi \hat{\omega} \nu$

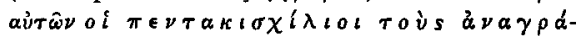

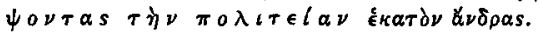

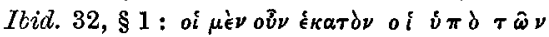

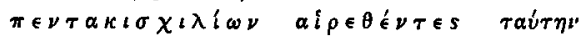
ả๊

20 Op. cit. pp. 426-433. The decisive arguments are these: (a) The whole subsequent course of the revolution is inexplicable save on the assumption that the Five Thousand never met, and indeed never could meet, because their membership had not been determined. Unless this point is taken for granted, Thucydides' account, which is our only account, of the later stages of the revolution, falls to the ground. (b) In the speech Pro Polystrato, $\$ 13$, it is

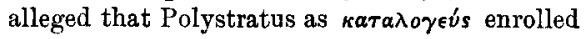
not 5000 but 9000 members. Such a plea could not have been made if an anthentic list of approximate 5000 heads had ever been published: the falsehood would have been too barefaced (Ledl p. 46). (c) After the fall of the Four Hundred, when the government was made over nominally to the 'Five Thousand,' this term was made to include $\delta \pi \delta \sigma o l \quad \delta \pi \lambda \alpha$

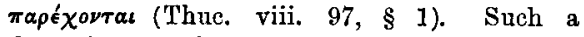
definition would have been quite unnecessary if a ready made list of 5000 had then been available.

It has been suggested that although the
Five Thousand were never completely constituted and took no part in the later stages of the revolution, yet a quorum was appointed (Ballet, Musée Belge, 1898, p. 13 ; Volquardsen, pp. $128 s q q$.$) , or an assembly \tau \hat{\omega} \nu \not \Delta \pi \lambda \alpha \pi a \rho \in \chi 0-$ $\mu \dot{e}^{\prime} \omega \nu$ was convened in its stead (Kenyon $a d$ Ath. Pol. 30, § 1 : 3rd ed.), and elected the Constituent Committee of àvarpaфkîs in the manner outlined by Aristotle, This hypothesis hardly saves the credit of Aristotle, whose account even on this showing would be sub. stantially wrong. Nor does it square well with Thucydides. Had the 'Five Thousand' ever been convened in however imperfect a form, they could hardly have been eclipsed during the later stages of the movement to the extent which Thueydides supposes. (May, p. 67.)

21 Ath. Pol. 30-32, \$1.

22 The expression used by him is $\kappa \nu \rho \omega \theta \theta^{\prime} \nu \tau \omega \nu$

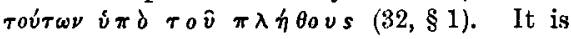
a matter of dispute whether $\pi \lambda \hat{\eta} \theta$ os refers to the Five Thousand or to the democratic

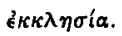

$3332, \$ 1$.

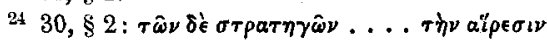

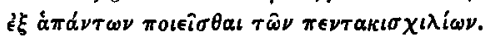

25 The administration was confided turn and turn-about to four sections of the Five Thousand, which letween them comprised its full membership of men above 30 years of age $(30, \S 3)$. Fach section would thus be abont one thousand strong. 
The same conclusion follows from several other considerations. In the first place, it is noteworthy that both the constitutions described by Aristotle were quite inadequate to the purpose of the conspirators: neither could have sanctioned the autocratic power which they had in fact usurped. In the 'definitive' scheme the government was permanently and exclusively vested in the Five Thousand as represented by four Grand Committees, none of which could have been brought under the control of Peisander's group. Moreover the members of the Five Thousand instead of being merely permitted were actually compelled to exercise their power. ${ }^{26}$ A more effective way of preventing the actual concentration of authority in the hands of a

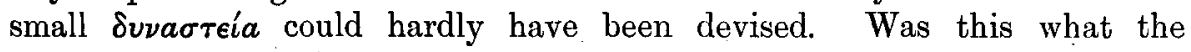
revolutionists had risked their bones to attain?

Again, the 'provisional' constitution, howbeit more favourable to the plotters, contained an ample safeguard against the usurpation of a narrow coterie, in that the ius suffragii remained in the hands of the generality of franchise holders. According to this scheme the Four Hundred were to be appointed by a very wide electorate, which could not have remained for any length of time under the influence of Peisander and his accomplices. ${ }^{27}$ But if the revolutionists had been unable to obtain a working majority among the Four Hundred the concentration of power in the hands of that body would not have been of the slightest service to them. Furthermore the double process of election ('́) $\pi \rho \circ \rho i^{\prime} \tau \nu$ ) which was to be applied in the case of the Four Hundred would have told heavily against the usurpers. 'He who nominates governs' is a truth well known to all political wirepullers, and in the election of the Four Hundred it was a vital matter for the ringleaders that the nomination of Candidates for the new Council should be as far as possible in their hands. And it was of no less importance from their point of view that the elections should be completed quickly, for fear that a counterrevolution might be organised before they had got their new government into full working order. But election $\epsilon \kappa \pi \rho \circ \rho i \tau \omega \nu$ was a complicated operation which required a large outlay of time, and the preliminary list of candidates which it called for was so large that the nominations could not have been easily pre-arranged by intrigue.

At this point it may be objected that Aristotle's account of the election of the Four Hundred under the 'provisional' constitution is confirmed by a passage in the speech Pro Polystrato, where Polystratus, who was undoubtedly a member of the Four Hundred, is stated to have been elected $\dot{v} \pi \dot{o} \tau \hat{\omega} \nu \phi v \lambda \epsilon \tau \hat{\omega} \nu .^{28}$ But how much can safely be inferred from this assertion? We are not told explicitly whether the election in question

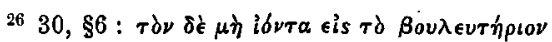

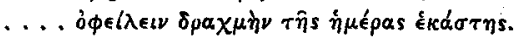

27 The Four Hundred were to be elected $\boldsymbol{k}_{\kappa}$

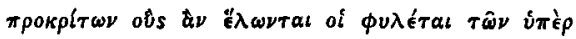

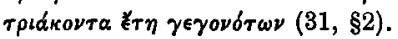

Meyer (p. 426 and n.) suggests that the electorate was terrorised into returuing the
}

candidates submitted by the Four Hundred. This might have been practicable for once, but could not 'easily have been repeated. In an adjacent passage Meyer expresses his surprise that any oligarch at all should have bee returned on the system described by Aristotle.

28 [Lys.] xx. \$ 2. 
referred to the Council of Four Hundred rather than to any other body.

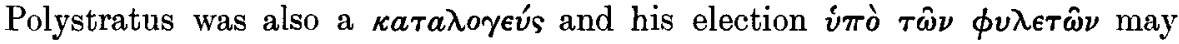
just as well refer to this office, to which appointments were in all probability made by the tribes. ${ }^{29}$

Another difficulty in the way of accepting Aristotle's 'provisional' constitution as a working scheme of government in 411 B.c. has recently been pointed out by Kahrstedt. ${ }^{30}$ Aristotle declares the Four Hundred to have been elected phyle-wise. From this one would naturally infer that the new Council was divided into prytanies, in accordance with a long-established and convenient practice. But there is evidence that during the rule of the Four Hundred the customary method of dating by prytanies was suspended, ${ }^{31}$ and this points strongly to the division into prytanies having likewise been discontinued.

Lastly, there remains the question, why did the revolutionists go out of their way to frame two constitutions, one of which was admittedly of no immediate use to them?

For this problem various explanations have been offered. Wilamowitz has suggested that the usurpers had set their hearts on the 'definitive' scheme, but that they durst not put it forthwith into operation, lest the public at Athens should cry out that the new government was too radical, and the citizens on service at Samos should complain that they had not been consulted in a matter which must ultimately concern them too. ${ }^{32}$ If this was really what the usurpers had in mind, they were strangely lacking in common sense. If the 'definitive' constitution was too violent a departure from old established ways in Athens, what are we to think of the 'provisional' instrument? In politics it cannot be assumed that where a mild dose of revolution irritates a strong dose will induce sleep. Again, it would have been a topsyturvy procedure, first to elaborate a constitution for the pleasure of the citizens at Samos, and then to ascertain where their pleasure really lay: constitution-making on these lines would have become a reritable Penelope's task.

Another conjecture has been made by Costanzi, ${ }^{33}$ who assumes like Wilamowitz that the 'definitive' scheme was that which best expressed the aspirations of the usurpers, but supposes that a provisional government of more strictly oligarchic character was required to conciliate the king of Persia, whose aid the Athenians were seeking at that time. This theory, however, is vitiated by the fact that the negotiations in question had broken down before the climax of revolution, and that Peisander, who had been a leading agent in these diplomatic changes, was perfectly well aware of their failure.

29 Kriegel, p. 31.

30 P. 254.

31 In a treasure list of $412 / 11$ B.C. (I.G. i. 184) the earlier entries are dated in the usual

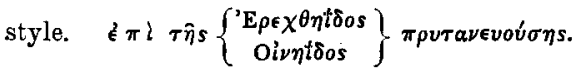

A later entry, belonging to the summer of

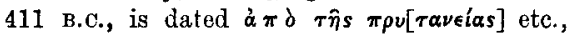
thus showing that the cycle of prytanies had been interrupted.

${ }^{32}$ Aristoteles und Athen, ii. pp. 114, 116.

33 P. 99. 
Some critics, and notably Ed. Meyer, ${ }^{34}$ have endeavoured to fit the boot on the other leg. They assume that the 'provisional' constitution was really intended by the revolutionists to remain in force for ever, and that the 'definitive' scheme was a mere plaything to be dangled before the eyes of suspicious democrats, or of oligarchs of the more moderate type. In favour of this view it may be pointed out that a very similar expedient was used by the thirty Tyrants in 404 B.C., who a'ei "̈ $\mu \epsilon \lambda \lambda o \nu$ to draw up a permanent constitution, and so constituted their temporary dominion ad infinitum. Also it is clear from Thucydides that Peisander and his party did indeed make a great point of putting off their critics with promises of a more liberal administration. But even so our way is not clear of all difficulties. As has been pointed out above, ${ }^{35}$ the 'provisional' constitution, though better adapted to the needs of the usurpers than the 'definitive' one, nevertheless ran counter to their interests on several vital points. Furthermore, a closer inspection of Thucydides' story reveals that the promises of reform with which the usurpers sought to amuse the malcontents were different from those contained in Aristotle's 'definitive' programme. Their

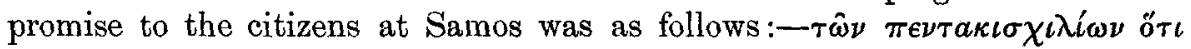

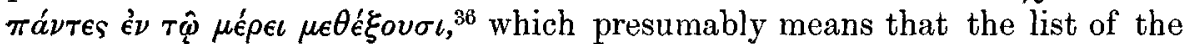
Five Thousand would from time to time be revised so as to include

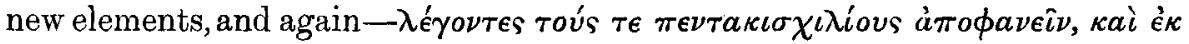

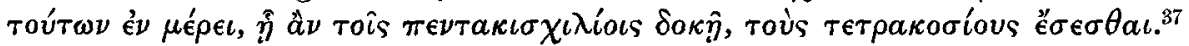
Neither of these provisions resembles anything that is contained in the 'definitive' constitution of Aristotle: the latter rather suggests a prolongation of the 'provisional' government. As there is no independent reason for doubting the truth of Thucydides' account, it must be admitted that the 'definitive' constitution cannot be explained away as a piece of make believe.

Summing up, therefore, we may conclude with some degree of confidence that Aristotle's two constitutions do not belong to the context into which they have been inserted, and that their author did not know how the Four Hundred were really constituted.

If we now turn to Thucydides' narrative, ${ }^{38}$ we find that his version of events is as follows:-

(1) In the Ecclesia at which the $\xi v \gamma \gamma \rho a \phi \epsilon \hat{\varsigma}$ presented--or rather failed to present-their report, Peisander proposed a string of resolutions, including :-

(a) abolition of payment for public service;

(b) election of five $\pi \rho \epsilon_{\epsilon} \delta \rho \iota$ to act as a nucleus of the new Council of Four Hundred: co-optation of these by further 100 members; cooptation of the Hundred thus appointed of further 300 councillors;

(c) investment of the new Council with autocratic powers, and with discretion to convene (or not to convene) the Five Thousand at their pleasure.

${ }_{34}$ Pp. 433-5. $\quad{ }^{35}$ P. $5 . \quad 36$ viii. $86, \S 3 . \quad 37$ viii. $93, \S 2 . \quad 33$ viii. $67-70$.


(2) These proposals were carried nem. con., a fact which was no doubt due to the Ecclesia having been summoned in an unusual place outside the city walls and being therefore presumably packed with Peisander's partisans.

(3) On the same day ${ }^{39}$ the conspirators at a certain chosen moment marched upon the Council House with a large armed escort and unceremoniously turned out the old (democratic) Council of Five Hundred, which was still sitting at the time. The acquiescence of the Five Hundred was procured not merely by show of force, but by payment to the evicted councillors of a full prytany's wages.

(4) Having thus taken possession of the Council House the usurpers and their Council of Four Hundred assumed control of the Executive and made further alterations in the government so as to suit their special purpose.

This story is open to several criticisms.

(1) It credits Peisander with a motion (payment for state service) which more probably belongs to the $\xi u \gamma \gamma \rho a \phi \epsilon i s^{40}$ Worse still, it omits to mention the resolutions of the $\xi v \gamma \gamma p a \phi \in \hat{s}$ which provided for the constitu-

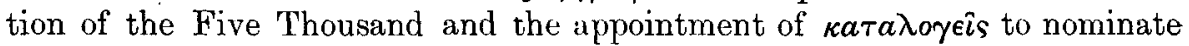
these. ${ }^{41}$

(2) It doés not explain satisfactorily what part was played by the old Council of Five Hundred during the climax of the revolution. One would like to know $(\alpha)$ why the $\pi \rho v \tau a ́ v e \iota s$ of the Council, who alone were entitled to convene an Ecclesia, permitted it to be held outside the city walls. (b) Why did the same $\pi \rho v \tau a ́ \nu \epsilon \iota s$, who presumably presided over the Ecclesia in accordance with existing custom, permit Peisander to propose a final vote on various revolutionary motions which required to be preconsidered, if motion ever did, by the Council? (c) Why did the whole Council of Five Thousand, which ex hypothesi had been dissolved by the acceptance of Peisander's resolutions, scamper back to the Council House in order to deliberate in vacuo? Was this due to force of habit? (d) Why did the conspirators, who had found the Five Hundred so strangely complaisant. in legalising the revolution, incontinently pounce upon them and apply both force and bribery on a magnificent scale in order to get rid of them? ${ }^{42}$

To most of these questions an answer has never yet been attempted and the explanations put forward in connexion with others will hardly

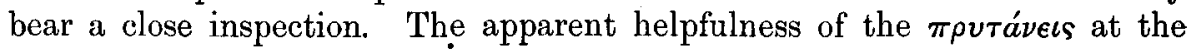
critical Ecclesia has been put down to collusion, ${ }^{43}$ or to terrorism exercised

${ }^{39}$ This point has been called into doubt. At the outset of his narrative Thucydides merely says that episode (3) occurred which might mean anything. Further down, however, he explains that episode (3) happened

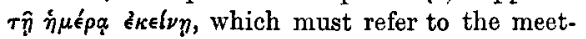
ing-day of the packed Ecclesia at Colonus.

${ }^{40}$ See above, pp. 3-5.

41 In a previous chapter $(65, \$ 3)$ Thucydides relates that the revolutionists had made propa- ganda in favour of constituting a body of Five Thousand. But he nowhere records the enactment of this measure, which certainly was a sufficiently important step in the revolution to

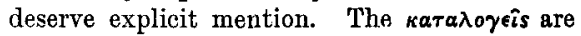
not brought into notice by him at all.

42 See the pertinent inquiries made by Kahrstedt (pp. 238-240, 246) and Ledl (p. 53). ${ }^{43}$ Köhler, p. 808, n. 1. 
by the usurpers. ${ }^{44}$ The former hypothesis is quite out of the question, for the appointment of Councillors under the democratic constitution was so contrived as to exclude all chance of the prytanies ever falling into the hands of the oligarchic clique. The latter explanation is prima facie plausible, but increases the difficulty of meeting questions $(c)$ and $(d)$.

A mistake on 'Thucydides' part must therefore be assumed. To point out its exact nature is not an easy matter. Kahrstedt ${ }^{45}$ cuts the knot by supposing that the critical Ecclesia was not a constitutional one, but a 'secessio in montem Colonum' which the conspirators organised without

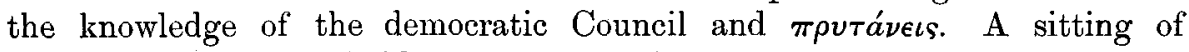
the old Council was held on the same day, when news was brought of the usurpers' irregular proceedings at Colonus; whereupon these latter, not having as yet come into touch with the Five Hundred, and apprehending that they had met in order to organise a counter-revolution, lost no time and spared no effort or expense in putting their supposed enemies out of action. After these precautions had been taken, it only remained for Peisander and his partisans to take the place of the evicted councillors, and having passed a series of appropriate $\pi \rho \circ \beta o v \lambda \epsilon u ́(a \tau a$ confirming the business done at Colonus, to convene a regular Ecclesia by means of the newly appointed $\pi \rho v \tau a$ ue new Council's resolutions for ratification.

It will be seen that this version of events is far more intelligible than that which Thucydides presents to us. But it is not altogether free from objections. In the first place, the action of the conspirators in first ignoring the old Council and subsequently rounding upon it is somewhat puzzling. Surely Peisander's party was aware of the great power which the Council could exercise over the executive, and of the decisive part which it might play in using that power to check the revolution. It would have been a strange act of negligence for the usurpers to show their hand at Colonus without first of all making sure of the Five Hundred. On Kahrstedt's own showing a slight hitch in the conspirator's plans might have enabled the Council to frustrate the entire plot.

Again, the procedure of the revolutionists as reconstructed by Kahrstedt would have involved more than one serious breach of the constitution. To

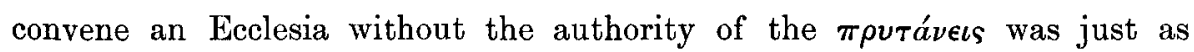
illegal as to expel the council at the point of the sword. But it is conceded on all hands that the usurpers sought to comply with legal forms wherever possible. One would sooner believe that their usurpation was carried out with a greater show of constitutional correctness than is compatible with the present theory.

Lastly, the mistake which Kahrstedt ascribes to Thucydides, the confusion of a contio with a properly convened comitia, is a more serious one than we should care to accept if we could help it.

An alternative suggestion by Judeich ${ }^{46}$ represents the assembly at

$$
4 \text { Busolt, p. 1478, n. } 1 . \quad 45 \text { Pp. 244-6. } 46 \text { P. } 308 .
$$


Colonus as having been convoked and held in all proper form, and goes on to

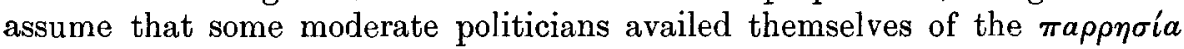
which was ex hypothesi accorded at the meeting in order to defeat the proposals of the conspirators; whereupon Peisander's party abandoned all show of quasi-legal procedure and secured at any rate the essence of power by an impromptu attack upon the Council.

This theory is no less consistent than Kahrstedt's. But it has some weak points. Its account of proceedings at Colonus completely overthrows Thucydides' authority, who expressly asserts that no opposition was there offered; and the alleged success of the moderates rests on no evidence save the supposed authenticity of the rather liberal constitutions described by Aristotle. ${ }^{47}$ But it has been pointed out above that Aristotle's constitutions can in no case be brought inte connexion with the business done at Colonus. Again, if the summoning of the Ecclesia to Colonus was indeed an act of the regular $\pi \rho v \tau a \dot{\nu \epsilon \iota s, ~ w h a t ~ w a s ~ t h e ~ r e a s o n ~ w h i c h ~ i n d u c e d ~ t h e s e ~ o f f i c i a l s ~ t o ~}$ transfer the assembly to such an unusual place? Judeich's conjecture that the site was chosen because of its strategic position, as commanding the approach to the city from Deceleia, should be sufficiently refuted by a glance at the map of Attica.

In default of a better explanation it may be suggested that in reality the eviction of the old Council preceded the convention at Colonus. We must then suppose that the usurpers first of all made their descent upon the Council House; next, they constituted themselves into an extempore Council and passed a $\pi \rho \circ \beta o v \lambda_{\epsilon} v \mu a$ recommending the creation of a permanent plenipotentiary Council of Four Hundred; next, they instructed their newly installed $\pi \rho v \tau a ́ \nu \epsilon \iota s$ to convene an Ecclesia at Colonus; next, at Colonus they put up Peisander to move the adoption of the aforesaid $\pi \rho o \beta o u ́ \lambda \epsilon u \mu a$; lastly, upon confirmation of Peisander's resolution they constituted themselves and their followers to form the permanent Council of Four Hundred. 48

On behalf of this view the following points may be urged:-(1) The procedure of the conspirators as here presented was most in accord with common sense. Although de jure the most important phase of the revolution

\footnotetext{
47 Judeich himself has expressed doubts on the applicability of these documents (p. 301).

48 The sequence of events as given above fits in well with the dates provided by Aristotle $(32, \S 1)$ : Thargelion 14 th for the dissolution of the old Council; Thargelion 22nd for the installation of the permanent Council of Four Hundred. The interval of eight days would be taken up with the convocation of the Ecclesia at Colonus and the election of the new Council in accordance with tha vote of that assembly. In the meantime the government was no doubt carried on by the arch-conspirators without legal sanction.

There is no need to suppose, with Judeich
}

(p. 305), that the event of Thargelion 14th was the formal abrogation of the Council (by the Ecclesia at Colonus), and not its actual dispersion (by the coup d'etat of the conspirators). The date in question may quite well have been preserved owing to the fact that no records of the old Council subsequent to Thargelion 14th remained over in the Athenian archives. At the same time it is not impossible that, as Thucydides asserts, the actual dispersion of the old.Council and its formal dissolution at Colonus took place on the same day. In this case the date Thargelion 14 th may of course be made to do duty for both events. 
would be the formal institution of the Four Hundred at Colonus, de facto the decisive movement consisted in the expulsion of the democratic Council. This body was the nerve centre of the Athenian administration. So long as it was allowed to remain in office it retained the means of organising

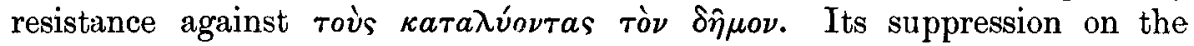
other hand entailed the paralysis of all public life in Athens. Obviously, therefore, everything depended on the success of the conspirators' attack upon the old Council, and until this essential point had been carried it was not in the least worth while their opening business with the Ecclesia.

Again, on the present hypothesis the illegalities of the usurpers are limited to the single act of supplanting the democratic Council by force of threats and bribery. The remaining procedure of the usurpers, when once they were installed in the old Council's place, was formally at least quite correct. The decisive meeting of the Ecclesia was no doubt summoned to an abnormal place, and its character may have been highly unrepresentative, yet having been convened in due form by $\pi \rho v \tau a ́ \nu \epsilon \iota s$ it wore at least an outward show of legality.

Lastly, the authority of Thucydides is maintained at every point, save only on one question of chronology. And even here 'Thucydides' mistake is reduced to a minimum if we follow him, as is quite possible, in supposing that the expulsion of the Council and the convention at Colonus took place on the same day, though not in the order of succession indicated by him.

It may be agreed, then, that in some respects 'Thucydides' account of the setting up of the Four Hundred needs correction. In other particulars his authority should be allowed to hold good. Chief of all, Thucydides alone relates what is by far the most important fact of the whole story, that the revolution, although disguised under legal forms, was essentially an act of violence, and that the conspirators' plan could not have been carried out without the forcible expulsion of the old Council and the secession of the Ecclesia to Colonus. Again, we may follow Thucydides on the important question of the prerogatives of the new Council and the method appointing it. The later course of the revolution compels us to assume that the dominion of the Four Hundred was quite despotic, and that the membership of this body was entirely under the control of a few ringleaders. The accuracy of 'Thucydides' narrative on these points need not therefore be called into question. ${ }^{49}$

49 Doubts have been raised as to the election of five $\pi \rho \delta \epsilon \delta \rho o t$ as a nucleus for the new Council (Köhler, p. 811 ; Kuberka, p. 352 ; Ledl. p. 53). Unless we retain our belief in Aristotle's 'provisional' constitution as belonging to this context, there is no need here to cavil at Thucydides. It is probable enough that the $\pi p \delta \in \delta \rho o$ เ were chairmen as well as leaders of the Four Hundred, as the name declares.

Many critics have adopted the suggestion of Wilamowitz (op. cit. ij p. 357) that the

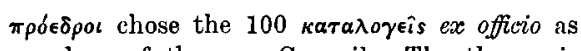
members of the new Council. The theory is

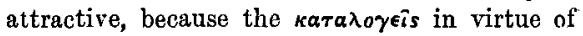
their occupation would best know how to co-opt safe men into the remaining 300 seats. But there is nothing in the speech Pro Polystrato to compel such a conclusion. Also it is improbable

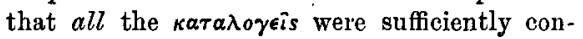
vinced oligarchs. In any case the question is of slight importance. 


\section{D.-The later Stages of the Movement.}

The only remaining datum supplied by Aristotle relates to the negotiations of the Four Hundred with Sparta. The Four Hundred, so his story runs, held out for a settlement on the basis of uti possidetis, and on failing to obtain these terms broke off all communications with the enemy. ${ }^{50}$ Thucydides knows nothing of a stand made by the Four Hundred on behalf of an uti possidetis clause; on the contrary he knows full well of further overtures on their part which amounted to nothing short of flat treason. ${ }^{51}$ On this issue there can be no doubt that Thucydides has the better account. It stands in perfect accord with the dénouement of the revolution as related by himself, and with the official record of the proceedings taken against the conspirators after their fall. ${ }^{52}$

\section{General Conclusion.}

It will be seen that for the earlier stages of the revolution Aristotle is generally to be preferred to Thucydides; for the climax of the movement, and still more so for its catastrophe, Thucydides is the superior authority. But in reconstructing the whole episode the only safe course is to observe a strict impartiality between our two sources, and to seek out the best in each without any preconceived notions.

\section{Appendix.}

In the preceding pages the task of tracking out the sources from which our ancient authorities drew their information, both good and bad, has been studiously shirked. Speculations of this kind are apt only to throw fresh darkness on the subject. ${ }^{53}$ But there is one special problem which admits of a detailed investigation and seems at the same time worth attempting to solve-what is the origin of Aristotle's constitutions?

Critics who reject these documents as evidence for the events of 411 B.C. usually dismiss them as mere forgeries, perpetrated by some actual ringleader of the revolution, say Antiphon or Theramenes, or by a sympathetic pamphleteer of later date, and intended to present the conspiracy in a favourable light. ${ }^{54}$ On behalf of this view it may be argued that Aristotle's treatise contains several chapters, and notably the one on Draco's constitution, which are commonly agreed to rest on some falsification ; and that generally

\section{$5032, \S 3$}

31 viii. $70, \S 2 ; 71, \S 3 ; 86, \S 9 ; 90, \$ \S 2-6$.

52 [Plutarch], Vitae $X$. Oratorum, i. $\$ \S 23-27$.

53 It is sufficient here to point to the hopeless diversity of modern opinion on the nature and value of our informants' sources.

54 The former view is expressed by Ledl (p. 4.7), the latter by May (p. 64), Kahrstedt (pp. 254-5) and, more emphatically, by v. Mess (p1. 366-376). 
speaking the authors of the fourth century were unscrupulous in their treatment of earlier Athenian history. ${ }^{55}$

On the other hand it must be recognised that these forgers exercised some discretion in the pursuance of their art. The episodes which they invented generally turn out to belong to a fairly remote period, Solon's age by preference. The history of recent times was treated by them more respectfully. And this need cause no wonder. After the stormy period of the Four Hundred and of the Thirty Tyrants the Athenians took good care

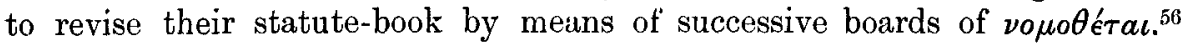
It is unlikely, therefore, that a fourth-century pamphleteer would have ventured to fabricate documents of a period whose records had been passed under a specially strict review, or that Aristotle (or his informant) would not have found him out in case of his taking the risk.

It may also be surmised that a forger would have made his documents wear a more plausible air than Aristotle's acts possess : these latter, by reason of their curious details, and by the fact of their being double-barrelled, were better calculated to rouse than to allay suspicion. ${ }^{57}$

As for Antiphon and Theramenes, one is at a loss to know why they should have added forgery to their other accomplishments. If these men wanted to obtain a quasi-legal justification for their revolution, they had far

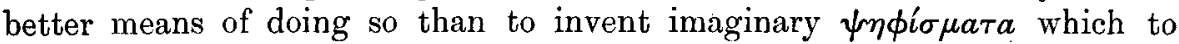
everybody's knowledge had never been enacted by the Ecclesia. Such an expedient would have been unworthy of Antiphon's a $a \epsilon \tau \eta \dot{\eta}$ or Theramenes'

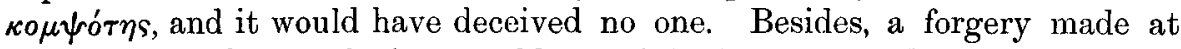
the time of the revolution would certainly have been discovered by the

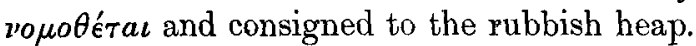

An alternative explanation has been put forward by Beloch, ${ }^{58}$ who would preserve Aristotle's documents as authentic, but would refer them to the events following upon the fall of the Four Hundred. This theory which has never been developed by its author, has found strangely little favour. Yet a closer study of it may show that there is much to be said on its behalf.

That the period ensuing upon the collapse of the revolution was a time of extensive constitutional experiment in Athens is known to us both by an

55 To quote but a few glaring instances, it is notorious that Andocides and Isocrates distorted Athenian history with the utmost sang froid.

56 One such board was appointed after the fall of the Four Hundred (Thuc. viii. $97, \S 2$ ), another after the fall of the Thirty Tyrants (Andocides, De Mysteriis, \$82-4).

${ }_{57}$ Ledl, who argnes cleverly against the supposed indebtedness of Aristotle to an oligarchic pamphlet, points out that his information cannot at all events have come from a 'Theramenic' source. Such a record would have been quite explicit about the unreality of the Four Hundred and about Theramenes' attempts to call them into being, whereas Aristotle is sadly confused on this point (pp. 40-42).

Sinilarly it may be argued that the Constitutions did not issue from Isocrates' factory, else they would certainly have ascribed an important rôle to the Areopagus, which in Aristotle's account is conspicuous by its absence. ${ }_{58}$ Griechische Geschichte, ii. p. 71, n. 2. 
explicit statement of Thucydides, ${ }^{59}$ and by a hardly less certain inference drawn from the appointment of a new board of $\xi v \gamma \gamma p a \phi \epsilon i s .{ }^{60}$ That the nature of these experiments should have been such as we read of in Aristotle's documents can be made probable on several grounds.

(1) The duplication of constitutions, which is so difficult to explain on any other lines, falls in well with the circumstances of this later period. One of the first tasks which the Athenians took in hand after the revolution was a thoroughgoing revision of their statute-book, for which purpose

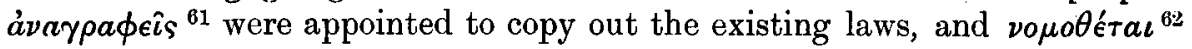
to sort and sift them. Now pending the completion of the revised code it was plainly inopportune to work out in detail a constitution for permanent use, which might eventually turn out to conflict with laws of ancient standing. The only businesslike way of proceeding was to make shift for a while with an extemporised government and to postpone the enactment of a definite constitution until the new corpus iuris should have been prepared. This in fact was precisely what the Athenians did in a similar situation after the deposition of the Thirty Tyrants. ${ }^{63}$ What more natural than that they should have adopted the same course after the revolution of 411 B.c.?

(2) It has been seen above ${ }^{64}$ that both of Aristotle's constitutions presuppose the existence of an effective body of 'Five Thousand.' In the period now under discussion, and at no other period, such a body was called into actual being, and although its numbers were not clearly defined, it carried the title 'Five Thousand.' ${ }^{65}$

(3) Various features of detail in Aristotle's description of the 'provisional' constitution point to the same conclusion.

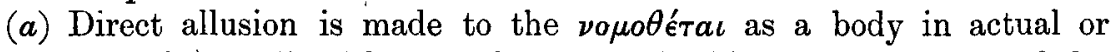
prospective existence. ${ }^{66}$. The appointment of this board is referred by Thucydides ${ }^{67}$ to the time after the revolution.

$(\beta)$ The 'provisional' Council was given wide discretion in the matter of calling ex-magistrates to account. ${ }^{68}$ This provision would be particularly appropriate to an epoch of settlement after a political upheaval. Under the dominion of the Four Hundred the executive had submitted willy-nilly to

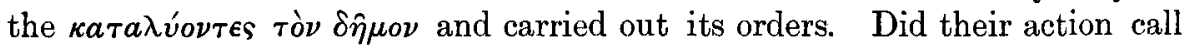

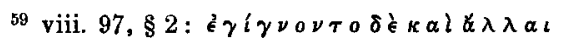

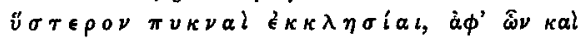

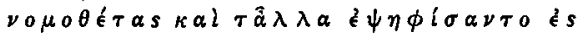
$\tau \dot{\eta} \nu \pi \circ \lambda เ \tau \in\{\alpha \nu$.

(4) I.G. i. 58. Busolt (p. 1538) connects this committee with the restoration of the Periclean democracy in 1410 B.c. But a return to such a familiar type of government did not necessitate the creation of $\xi v \gamma \gamma \rho \alpha \phi \epsilon i s$.

61 I.G. i. 61. Was this the board which Aristotle dates back to the critical period of the revolution and makes responsible for the drafting of his two constitutions $(29, \S 5 ; 32 \S 1)$ ?

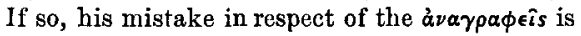

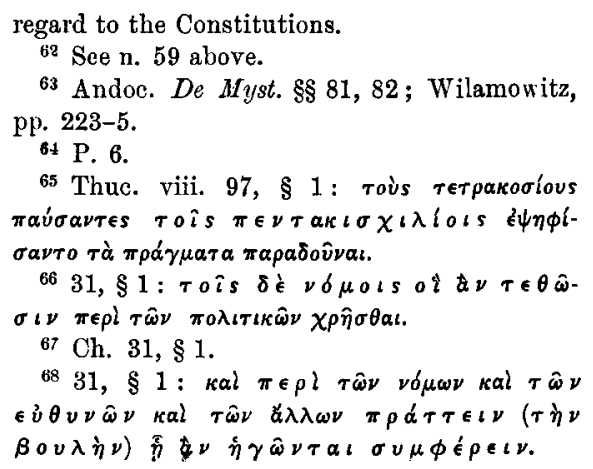
precisely the same as he made ex hypothesi with 
for punishment or not? ${ }^{69}$ Plainly this was a question which could better be settled by equity than by the strict letter of the law, and it was but reasonable that the cognition of these cases should have been transferred from the Dicasteries to the Council. ${ }^{70}$

$(\gamma)$ At the election of new $\sigma \tau \rho a \tau \eta \gamma o i$, which was to be made by the Council out of the 'Five 'Thousand,' this latter body was directed to be mustered in its equipment of war. ${ }^{71}$ This provision stands in remarkably close agreement with the statement of Thucydides, that after the fall of the Four Hundred the test of membership in the Five Thousand was the possession of a suit of armour. ${ }^{72}$

As the 'definitive' constitution was never put into operation, or only for a very short time, ${ }^{73}$ it has not left any record of action. No ancient author has therefore had any occasion to supply collateral evidence about it. The most remarkable feature in it, the institution of an acting Council of about 1000 members, has been criticised not unjustly ${ }^{74}$ on the score of its practical inexpediency: so unwieldy a body could never have dispatched business with the promptitude required during a state of war. It may be conjectured that these peculiarities were the outcome of the Athenians' experience at the time of the revolution. Clearly the 'Council of 1000' was intended to do away with the peculiar evils which impeded the proper functioning of the old Council and Ecclesia. The old Ecclesia could not in point of fact be truly representative when a large proportion of the citizens were bound to remain on garrison duty and to absent themselves from its deliberations: hence the ease with which Peisander's party contrived to pack the meeting at Colonus. On the other hand the old Council had proved to be too small in numbers to resist the coup d'état which was the main factor in the recent revolution. It was perhaps in order to obviate similar risks in future that the new

69 Compare the quandary in which the officials of the commonwealth found themselves when a Stualt restoration became imminent, and the efforts which they made to confer a quasi-legal sanction upon their recent acts by getting Cromwell appointed king.

70 That the dicasteries were still convened is proved by the document recording the impeachment of Antiphon ([Plutarch], Vitae $X$. Oratorum, i. \$23). But it is noteworthy that in this case the Council took the initiative by converting itself into a Grand Jury and finding a True Bill against Antiphon.

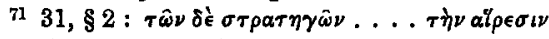

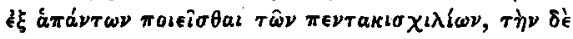

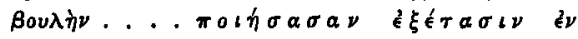
$8 \pi \lambda$ oเs Ė

72 viii, $97, \S 1$.

73 The only evidence in favour of this constitution having been put into operation is derived from an inscription of the period 411/10, in which mention is made of five $\pi \rho b e \delta p o t$ (Wil- helm in Ber. Wien. Akad., Anzeiger der philhist. Klasse, 1897, no. 26, p. 3). A board of such officials, five in number, is mentioned in Alh. Pol. 30, \& 5. But there is nothing to prevent our supposing that these $\pi \rho \delta \in \delta \rho \circ$ had also officiated under the 'provisional' scheme. On the other hand, the 'definitive' constitution can hardly have been carried into practice before 410 B.c. The time required by the ảvaypaфeis (who apparently were allowed four months for their work-Lysias, xxx. \& 2-, but in reality took much longer, $I . G$. i. 61) and by the kurypapeis to prepare the new code of laws, and for the Ecclesia to ratify it, would more than account for the remaining months of the year 411. But early in 410 B.c. the reaction set in by which the complete Periclean democracy was restored. Hence the 'definitive' constitution could only have functioned for a few weeks at the outside.

${ }^{74}$ Wilamowitz, pp. 121-3. 


\section{THE REVOLUTION OF THE FOUR HUNDRED AT ATHENS}

constitution created an unusually large Council and made over to it the work of the Ecclesia.

It may be objected that Aristotle's constitutions are not sufficiently democratic to have satisfied the Athenians after the recent fiasco of the oligarchy. But this argument need not carry much weight. As regards the 'provisional' government, at the time when this was in force the Peloponnesian War had reached a highly critical stage, and it was essential that Athens should have above all things a simple and strong government. It need not surprise us if the Athenians put up for a while with a more autocratic rule: after the fall of the Thirty Tyrants they committed themselves to an interim government of a similarly illiberal type. ${ }^{75}$ Again, there is no evidence that any strong feeling in favour of a completely restored democracy set in until after the 'definitive' constitution had been enacted. For two years previous to the revolution the moderate democrats had enjoyed an ascendancy over the radicals : this same current in favour of moderate constitutional reform need not have spent itself until some months after the revolution. Moreover if we turn once again to the events of 403 B.c. we shall find that the moderate democrats at that time were strong enough to propose a permanent settlement by which the franchise was to be restricted to landholders. ${ }^{76}$ The comparative exclusiveness of Aristotle's ' definitive' constitution should not therefore cause any misgivings.

As to the cause of Aristotle's error in antedating his constitutions, this can only be guessed at. If the documents which he has reproduced for us had carried a date in the usual style, or if he (or his source) had been acquainted with the real official record of the institution of the oligarchy, he could hardly have fallen into such a mistake at all. But it is very doubtful whether he had any such safeguards at hand.

After the fall of the oligarchs the archon Mnesilochus, who had inangurated the year 411/10 under their rule, was deposed. ${ }^{77}$ His successor, Theopompus, was not elected until after the enactment of the 'provisional' constitution.78

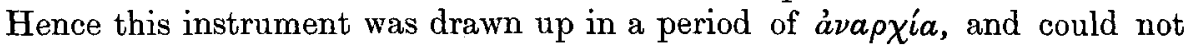

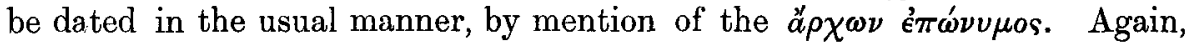
it is not unlikely that the Athenians expunged all official record of the revolution, thus leaving Aristotle without any authentic information concerning it.

But these speculations need not be carried any further. It is more important to have established the fact of Aristotle's error than to ascertain its causes.

M. O. B. Caspari.

75 Andoc. De Myst. $\$ \S 81-2$. The supreme authority was vested in a board of twenty, to whom a Council elected by lot was subsequently attached.

${ }^{76}$ See the $i \pi \delta \theta \epsilon \sigma \iota s$ to [Lysias] Or. XXXIV., and Wilamowitz, pp. 225-230.
77 Ath. Pol. 33, \$1.

78 In $31, \$ 1$ we read that the Council is directed $\tau \dot{\alpha} s \dot{\alpha} \rho \chi \grave{\alpha} s \kappa \alpha \tau \alpha \sigma \tau \hat{\eta} \sigma \alpha$. From this it may be inferred that Theopompus had not yet been appointed $\varkappa_{\rho \chi} \chi \nu \nu \dot{\varepsilon} \pi \dot{\omega} \nu \nu \mu o s$. 